\title{
The Effect of Esomeprazole on Cell Line Human Cervical Cancer
}

\author{
Azal H. Jumaa ${ }^{1}$, Ahmed Sami Jarad ${ }^{2}$, Wissam Sajid Hashim Al Uboody ${ }^{3}$ \\ ${ }^{1}$ AL-Yarmouk University College, Department Of Dentistry, Baghdad, Iraq, ${ }^{2}$ College of Veterinary Medicine, \\ University of Fallujah, Iraq, ${ }^{3}$ Department of physiology, College of medicine, Al Muthanna University/Iraq.
}

\begin{abstract}
Esomeprazole is an inhibitor of the proton pump that reduces gastric acidity and is used in indigestion treatment; Esomeprazole is a promising treatment for tumors, such as melanoma and B cell leukemia, through several mechanisms, including rapid cellular acidification and activation of many types of caspase enzymes, which in turn lead to the activation of cellular apoptosis

This work was designed to assess the toxicity of the (Esomeprazole) on (HeLa cell line) in vitro at concentrations starting from one - ten thousand $\mu \mathrm{g}$ / milliliter and compared with cytotoxicity of vincristine and methotrexate at concentrations between one - ten thousand $\mu \mathrm{g} /$ milliliter In 3 incubation periods

The results showed that the cellular toxicity of one $\mu \mathrm{g}$ / milliliter was a lot of more than the cellular toxicity of ten and a hundred $\mu \mathrm{g} /$ milliliter. The results additionally showed that toxicity of esomeprazole was considerably more than vincristine and methotrexate on HLA cells at seventy two hours.
\end{abstract}

Key word: esomeprazole, vincristine, Hela cancer cell line.

\section{Introduction}

Cervical malignant tumor is a common categories of cancer between female, lead to women's sexual ability and fertility ${ }^{(1)}$. Chemotherapy is that the backbone strategy for cancer treatment especially in the early stage in case of cervical cancer, is treated by surgery or irradiation with chemotherapy ${ }^{(2-5)}$. Chemotherapy kills both cancer cells and normal cells with a high split rate ${ }^{(6-14)}$, Common side effects of chemotherapy are nephrotoxicity, which usually associated with vincristine and methotrexate therapy

Several approaches to solve the toxicity of conventional cancer treatments have been developed, like using of natural agents as plant extract that may show a promising anticancer activity ${ }^{(15-23)}$.

Investigation about the efficacy of some drugs that already used to treat diseases other than cancer. it show a hopeful role in the handling of malignancy, such as aspirin, which acts as a protective agent for various types of Cancer (colorectal cancer), through a mechanism like suppress platelets aggregation ${ }^{(19)}$, also acetaminophen at the therapeutic dose was capable of killing liver cancer cells by turn activate apoptosis ${ }^{(24)}$. On the other hand, Omeprazole has the ability to rise the sympathy of the immune B-cell leukemia cell line to the vinblastine by several mechanisms, including an increase in cellular acidity ${ }^{(4)}$.

Omeprazole have been shown to have potential to reduce resistance of tumor cell to chemotherapy by altering the pathway of the transfer of lysosomes contains and autophagy that activate programmed cell death mechanism ${ }^{(3)}$. A mixture of esomeprazole and amygdalin reveled ability to suppress the growth of cervical cancer cells in vitro $(5 ; 23)$

\section{Martial and Method}

Proton pump inhibitor: Esomeprazole (nexium) (B) $40 \mathrm{mg}$ (AstraZeneca) was used in different concentrations ranging from one to $10000 \mu \mathrm{g} / \mathrm{mL}$. These concentrations were set by thinning of the medication with bovine serum unrestricted medium.

Chemotherapeutics agent; a)Vincristine sulphate $1 \mathrm{mg} / \mathrm{ml}$ vial (hospira UK.) was used at different concentration ranged between (1-10000) $\mu \mathrm{g} / \mathrm{ml}$, after 
dilution with bovine serum free medium

Methotrexate vial (50 mg/5cc - kocak / turkey) was used at different concentration ranged between (1-10000) $\mu \mathrm{g} / \mathrm{ml}$, after diluted with bovine serum free medium

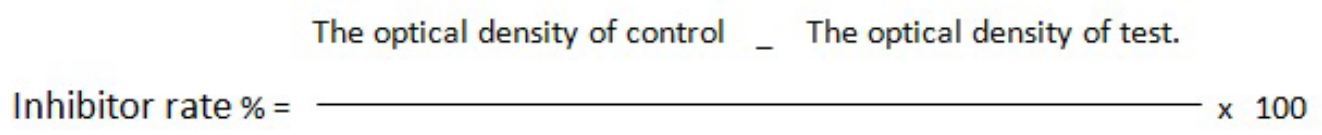

The optical density of control

\section{Cell line culture:}

The human cervical cell line cancer gotten from the unit of tissue culture in the Iraqi Center for Cancer and Medical Genetics Research . It were planting in tissue culture flasks with size $75 \mathrm{~cm} 2$ and with controlled conditions involving $5 \%$ of humidified, carbon dioxide on $37^{\circ} \mathrm{C}$ in RPMI-1640 media (Kigma Chemical, England) with fetal bovine serum at $10 \%$ (FBS), with add some anti biotic include pen.-strep. With concentration $1 \%(10)$.

\section{Cytotoxicity Assay:}

Human cervical cancer cells grown in microtiter plate (96wells) have been handled with a range of concentrations of each (esomeprazole, vincristine and methotrexate), cell density increases throughout the development period and also the cytotoxic effect of analytical agents strongminded once many incubation periods, ${ }^{(10)}$ each milliliter contains 1 X105 cells / ml, serum calf medium (10 percent) Used for seeding, plates were then incubated at $37 \mathrm{CO}$ for 24 hours to achieve cell attachment, followed by various serial dilution (1-10000 $\mu \mathrm{g} / \mathrm{ml}$ ) for esomeprazole, vincristine and methotrexate by victimization maintenance medium.

After twenty-four hours of incubation, cells were exposed (for each concentration tested, six replicates at $200 \mu \mathrm{l}$ ), two hundred $\mu \mathrm{l}$ of maintenance medium in addition to each control group well, the days of exposure were twenty-four, forty-eight, and seventy-two hours. The cultures were wrapped with self-adhesive paper, then transferred to incubators and then colored cells with MTT stain. Each well's optical density was scanned via a micro-ELISA at a wavelength of $550 \mathrm{~nm}(17 ; 10)$; the measurement of the substance frequency by using the subsequent equation ${ }^{(11)}$

\section{Statistical Analysis}

The Statistical Analysis System (SAS) ${ }^{(18)}$ used it to determine the outcome of varying parameter factors in the study.

\section{Results and Discussion}

\section{Esomeprazole cytotoxic effect:}

The findings of esomeprazole productivity inhibition of Hela cancer cells show an increase in productivity inhibition with an increase in the concentration of esomeprazole ranging from (10-10000) $\mu \mathrm{g} / \mathrm{ml}$, for every 3 incubation periods, except $(1 \mu \mathrm{g} / \mathrm{ml})$ wherever growth inhibition was significantly higher than $10 \mu \mathrm{g} / \mathrm{ml}$ to all incubation cycles, whereas there was no significant variation between the development reserve of $(1 \mu \mathrm{g} / \mathrm{ml})$ with $(1000 \mu \mathrm{g} / \mathrm{ml})$ for $24 \mathrm{hr}$. and $(1 \mu \mathrm{g} / \mathrm{ml})$ with $(100 \mu \mathrm{g} /$ $\mathrm{ml}$ ) for $48 \mathrm{hr}$. and $72 \mathrm{hr}$. incubation periods table (1).

Table (1) Effect of concentration and time in growth inhibition rate for Esomeprazole on Hela cancer cell line

\begin{tabular}{|l|l|l|l|l|}
\hline \multirow{2}{*}{ Concentration $(\boldsymbol{\mu g} / \mathbf{m l})$} & \multicolumn{2}{|l|}{ Time (hr.) } & \multirow{2}{*}{ LSD value } \\
\cline { 2 - 5 } & $\mathbf{2 4}$ & $\mathbf{4 8}$ & $\mathbf{7 2}$ & \\
\hline 1 & B $44.50 \pm 7.03 \mathrm{a}$ & A $32.46 \pm 9.08 \mathrm{a}$ & B $25.76 \pm 6.87 \mathrm{a}$ & $26.754 \mathrm{NS}$ \\
\hline 10 & C $9.66 \pm 2.28 \mathrm{a}$ & B $6.86 \pm 3.43 \mathrm{a}$ & C $3.93 \pm 1.45 \mathrm{a}$ & $16.012 \mathrm{NS}$ \\
\hline
\end{tabular}


Cont... Table (1) Effect of concentration and time in growth inhibition rate for Esomeprazole on Hela cancer cell line

\begin{tabular}{|l|l|l|l|l|}
\hline 100 & C $16.20 \pm 1.10 \mathrm{a}$ & A $14.90 \pm 8.02 \mathrm{a}$ & B $29.40 \pm 3.14 \mathrm{a}$ & 17.356 NS \\
\hline 1000 & B $35.30 \pm 6.36 \mathrm{~b}$ & A $23.83 \pm 2.45 \mathrm{~b}$ & A $89.66 \pm 0.66 \mathrm{a}$ & $13.70 * *$ \\
\hline 10000 & A $83.63 \pm 0.24 \mathrm{~b}$ & A $32.56 \pm 2.31 \mathrm{c}$ & A $88.76 \pm 0.97 \mathrm{a}$ & $5.037 * *$ \\
\hline LSD value & $13.845^{*}$ & $20.198^{*}$ & $11.828 *$ & ---- \\
\hline$*(\mathrm{P}<0.05)$. &
\end{tabular}

*Capital letter to compare among column means.

**Small letter to compare among row means,

Hormosis will explain the fluctuated growth inhibition of esomeprazole; hormetic result may be a common biological development in pharmacological medicine characterized by a reverse action of low concentrations compared with high concentration (16). The carbon-based biochemical pathway by hormesis action aren't well clear, it's imagined that low amounts of poisonous ingredient might start the healing process in the body ${ }^{(6)}$. This compound might increase the activity of anticancer agent whereas others may forestall the carcinogenic effect of some genotoxic compound ${ }^{(9)}$

Several recommended mechanisms will explain the toxicity of esomeprazole on Hela cancer cells, because the ability of esomeprazole to induce a lysosomes membrane permeabilization, inflicting increase outflow of lysosomes contains to the cytoplasm, inflicting lysis of cellular elements then death, additionally to hydrolytic activity, the lysosomal enzymes also can offer acidic atmosphere that encompasses a role in killing tumor cells $(8 ; 13 ; 15)$. Another mechanism in vitro via a fast intracellular acidification and activation of many caspase enzyme ${ }^{(5)}$, esomeprazole has ability to produce ROS in B cells neoplasm by many ways ${ }^{(4)}$.

Comparison among the cytotoxic effect of Esomeprazole, Vincristine and Methotrexate:

As shown in table (2) the manner of vincristine growth inhibition is dose and time dependent reflecting the fact of increase in vincristine cytotoxicity occurred with increase in time of its persistence inside cancer cells which occurred by several mechanisms including

mitosis blocking in metaphase, and blocks the ability of tubulin to polymerize to form microtubules binding by binding of microtubule protein, (tubulin) with esomeprazole then. Consist of Tubulin dimers that resulting from paracrystalline aggregates, leading to Spindle apparatus dysfunction, frozen in metaphase, impaired chromosomal segregation and cellular proliferation.

Permeabilization of lysosomal membrane is one of the vincristine anticancer mechanisms which Causing increase of lysosomes contains leakage to the cytoplasm and occurrence of cell death by the Degenerative activity of lysosomes contains and acidic conditions which equip by lysosomes acidic ambience.

When comparing between the growth inhibition of vincristine with esomeprazole as shown in table $(4,5,6)$, the results establish the development reserve of esomeprazole was more than vincristine gro $7 \mathrm{wth}$ inhibition on Hela cancer cells, especially at $24 \mathrm{hr}$. and $72 \mathrm{hr}$. incubation periods . reflecting the ability of esomeprazole to enhance permeabilization of lysosome membrane was more than the vincristine ability, that may related to the development of resistance toward vincristine action by efflux of vincristine through the special transport system P-glycoprotein (20) leading to less in persistence time of vincristine inside cancer cells, producing less in antineoplastic activity of vincristine which including inhibition in microtubules formation, with less ability to induce lysosomes membrane permeabilization as compared with the inducing ability of esomeprazole, where esomeprazole has a superiorities on vincristine to induce lysosomes membrane permeabilization which mainly related to the less resistance development toward esomeprazole activity.

While the result of methotrexate. Growth inhibition as shown in table (3) the growth inhibition at $72 \mathrm{hr}$. was less than the growth inhibition at $24 \mathrm{hr}$. especially at 10,100 and $1000 \mu \mathrm{g} / \mathrm{ml}$, this result reflecting the developments of resistance toward methotrexate Cytotoxicity, where there is several mechanism by 
which cancer cells follow to resistance the cytotoxicity of MTX included (weakening in methotrexate moving into cells, making of altered form of DHFR that have a fewer affinity for the dysfunction, intracellular height of intracellular DHFR, by quality enhancement or modified quality guideline and diminished capacity to combine methotrexate polyglutamate) ${ }^{(7) .}$ when comparing between the cytotoxicity of esomeprazole and methotrexate as shown in table $(4,5,6)$ and, the result of comparison demonstrated the growth inhibition of esomeprazole was more than the growth inhibition of methotrexate, that may relate to less resistance development toward esomeprazole .

Table (2) Effect of concentration and time in growth inhibition rate for Vincristine on Hela cancer cell line

\begin{tabular}{|c|c|c|c|c|}
\hline \multirow{2}{*}{$\begin{array}{l}\text { Concentration } \\
(\mu \mathrm{g} / \mathrm{ml})\end{array}$} & \multicolumn{3}{|l|}{ Growth inhibition } & \multirow{2}{*}{ LSD value } \\
\hline & $24 \mathrm{hr}$. & $48 \mathrm{hr}$. & $72 \mathrm{hr}$. & \\
\hline 1 & C $12.00 \pm 2.54 \mathrm{a}$ & B $18.00 \pm 2.54 \mathrm{a}$ & B $20.00 \pm 2.54 \mathrm{a}$ & $8.791 \mathrm{NS}$ \\
\hline 10 & $\mathrm{BC} 17.00 \pm 1.73 \mathrm{~b}$ & B $19.00 \pm 1.73 b$ & A $36.00 \pm 3.46 \mathrm{a}$ & $8.476 *$ \\
\hline 100 & $\mathrm{BC} 18.00 \pm 4.04 \mathrm{~b}$ & B $23.00 \pm 4.04 b$ & A $40.00 \pm 4.04 \mathrm{a}$ & $13.985 *$ \\
\hline 1000 & B $24.00 \pm 4.73 \mathrm{~b}$ & B $25.00 \pm 4.73 \mathrm{~b}$ & A $45.00 \pm 5.19 \mathrm{a}$ & $16.932 *$ \\
\hline 10000 & A $36.00 \pm 3.17 b$ & A $45.00 \pm 3.17 \mathrm{ab}$ & A $47.00 \pm 1.73 \mathrm{a}$ & $9.616 *$ \\
\hline LSD value & $10.758 *$ & $10.758 *$ & $11.343 *$ & ---- \\
\hline
\end{tabular}

Table (3) Effect of concentration and time in growth inhibition rate for methotrexate on Hela cancer cell line

\begin{tabular}{|c|c|c|c|c|}
\hline \multirow{2}{*}{$\begin{array}{l}\text { Concentration }(\mu \mathrm{g} / \\
\mathrm{ml})\end{array}$} & \multicolumn{3}{|c|}{ Inhibition effect of Methotrexate on cell viability \% } & \multirow{2}{*}{ LSD value } \\
\hline & $24 \mathrm{hr}$. & $48 \mathrm{hr}$. & $72 \mathrm{hr}$. & \\
\hline 1 & $\mathrm{C} 0 \pm 0.00 \mathrm{a}$ & $\mathrm{C} 0 \pm 0.00 \mathrm{a}$ & $\mathrm{C} 0 \pm 0.00 \mathrm{a}$ & $0.00 \mathrm{NS}$ \\
\hline 10 & B $17 \pm 0.62$ a & $\mathrm{C} 4 \pm 0.06 \mathrm{~b}$ & $\mathrm{C} 0 \pm 0.00 \mathrm{~b}$ & $7.95 *$ \\
\hline 100 & B $19 \pm 0.59 \mathrm{a}$ & $\mathrm{BC} 10 \pm 0.37 \mathrm{~b}$ & $\mathrm{C} 0 \pm 0.00 \mathrm{c}$ & $9.53 *$ \\
\hline 1000 & A $30 \pm 1.24 \mathrm{a}$ & $\mathrm{AB} 14 \pm 0.51 \mathrm{~b}$ & B $17 \pm 0.55 b$ & $7.69 *$ \\
\hline 10000 & A $37 \pm 2.49 \mathrm{a}$ & A $19 \pm 0.62 b$ & A $31 \pm 1.07 \mathrm{a}$ & $7.85 *$ \\
\hline LSD value & $8.531 *$ & $8.336 *$ & $4.602 *$ & - \\
\hline
\end{tabular}


Table (4) Effect of Esomeprazole, methotrexate and Vincristine on Hela cancer cell line at $24 \mathrm{hr}$.

\begin{tabular}{|c|c|c|c|c|}
\hline \multirow{2}{*}{ Concentration $(\mu \mathrm{g} / \mathrm{ml})$} & \multicolumn{3}{|l|}{ Treatment } & \multirow{2}{*}{ LSD value } \\
\hline & Esomeprazole & Vincristine & MTX. & \\
\hline 1 & B $44.50 \pm 7.03 \mathrm{a}$ & $\mathrm{C} 12.00 \pm 2.54 \mathrm{~b}$ & $\mathrm{C} 0.00 \pm 0.00 \mathrm{~b}$ & $14.942 *$ \\
\hline 10 & C $9.66 \pm 2.28 \mathrm{~b}$ & BC $17.00 \pm 1.73 \mathrm{a}$ & B $17.00 \pm 1.73 \mathrm{a}$ & $6.688 *$ \\
\hline 100 & C $16.20 \pm 1.10 \mathrm{a}$ & $\mathrm{BC} 18.00 \pm 4.04 \mathrm{a}$ & B $19.00 \pm 3.46 \mathrm{a}$ & $10.86 \mathrm{NS}$ \\
\hline 1000 & B $35.30 \pm 6.36 \mathrm{a}$ & B $24.00 \pm 4.73 \mathrm{a}$ & A $30.00 \pm 4.04 \mathrm{a}$ & $17.79 \mathrm{NS}$ \\
\hline 10000 & A $83.63 \pm 0.24 \mathrm{a}$ & A $36.00 \pm 3.17 b$ & A $37.00 \pm 2.30 \mathrm{~b}$ & $7.85 *$ \\
\hline LSD value & $13.845 *$ & $10.758 *$ & $8.531 *$ & ---- \\
\hline
\end{tabular}

Table (5) Effect of concentration and time in growth inhibition rate for Esomeprazole, methotrexate and Vincristine on Hela cancer cell line at $48 \mathrm{hr}$.

\begin{tabular}{|c|c|c|c|c|}
\hline \multirow{2}{*}{ Concentration $(\mu \mathrm{g} / \mathrm{ml})$} & \multicolumn{3}{|l|}{ Treatment } & \multirow{2}{*}{ LSD value } \\
\hline & Esomeprazole & Vincristine & MTX. & \\
\hline 1 & A $32.46 \pm 9.08 \mathrm{a}$ & B $18.00 \pm 2.54 \mathrm{a}$ & $\mathrm{C} 0.00 \pm 0.00 \mathrm{~b}$ & $18.850 *$ \\
\hline 10 & B $6.86 \pm 3.43 \mathrm{ab}$ & B $19.00 \pm 1.73 \mathrm{a}$ & $\mathrm{C} 4.00 \pm 1.15 \mathrm{~b}$ & $14.335 *$ \\
\hline 100 & A $14.90 \pm 8.02 \mathrm{a}$ & B $23.00 \pm 4.04 \mathrm{a}$ & $\mathrm{BC} 10.00 \pm 2.30 \mathrm{a}$ & $18.52 \mathrm{NS}$ \\
\hline 1000 & A $23.83 \pm 2.45 \mathrm{a}$ & B $25.00 \pm 4.73 \mathrm{a}$ & $\mathrm{AB} 14.00 \pm 4.04 \mathrm{a}$ & $13.36 \mathrm{NS}$ \\
\hline 10000 & A $32.56 \pm 2.31 \mathrm{~b}$ & A $45.00 \pm 3.17 \mathrm{a}$ & A $19.00 \pm 3.46 \mathrm{c}$ & $10.46 *$ \\
\hline LSD value & $20.198 *$ & $10.758 *$ & $8.336 *$ & ---- \\
\hline
\end{tabular}

Table (6) Effect of concentration and time in growth inhibition rate for Esomeprazole, methotrexate and Vincristine on Hela cancer cell line at $72 \mathrm{hr}$.

\begin{tabular}{|l|l|l|l|l|}
\hline \multirow{2}{*}{ Concentration $(\mu \mathrm{g} / \mathrm{ml})$} & \multicolumn{2}{|l|}{ Treatment } & \multicolumn{2}{l|}{ LSD value } \\
\cline { 2 - 5 } & Esomeprazole & Vincristine & \multicolumn{1}{l|}{ MTX. } & $14.64 *$ \\
\hline 1 & B $25.76 \pm 6.87 \mathrm{a}$ & B $20.00 \pm 2.54 \mathrm{a}$ & C $0.00 \pm 0.00 \mathrm{~b}$ & $9.761 *$ \\
\hline 10 & C $3.93 \pm 1.22 \mathrm{~b}$ & A $36.00 \pm 3.46 \mathrm{a}$ & C $0.00 \pm 0.00 \mathrm{~b}$ & $10.23 *$ \\
\hline 100 & B $29.40 \pm 3.14 \mathrm{~b}$ & A $40.00 \pm 4.04 \mathrm{a}$ & C $0.00 \pm 0.00 \mathrm{c}$ & $11.43 *$ \\
\hline 10000 & A $89.66 \pm 0.66 \mathrm{a}$ & A $45.00 \pm 5.19 \mathrm{~b}$ & B $17.00 \pm 2.31 \mathrm{c}$ & $6.086 *$ \\
\hline \hline LSD value & A $88.76 \pm 0.97 \mathrm{a}$ & A $47.00 \pm 1.73 \mathrm{~b}$ & A $31.00 \pm 2.31 \mathrm{c}$ & --- \\
\hline$(\mathrm{P}<0.05)$. & $11.828 *$ & $11.343 *$ & $4.602 *$ & \\
\hline
\end{tabular}

${ }^{*}$ Capital letter to compare among column means. 
**Small letter to compare among row means,

\section{Conclusion}

This study prove that Esomeprazole have a promising anticancer activity against human cervical cancer cells with superiority above vincristine and methotrexate cytotoxicity.

Acknowledgment: The author is thankful to Al Mustansiriya University $\backslash$ Iraqi center for cancer and medical genetic research for their support.

Ethical Clearance: The Research Ethical Committee at scientific research by ethical approval of both environmental and health and higher education and scientific research ministries in Iraq

Conflict of Interest: The authors declare that they have no conflict of interest.

Funding: Self-funding

\section{References}

1. Adam E, Kaufman RH, Adler-Storthz K. A prospective study of association of herpes simplex virus and human papillomavirus infection with cervical neoplasia in women exposed to diethylstilbestrol in utero. Int $\mathrm{J}$ Cancer; 1985;35(1):19-26.

2. American Cancer Society. Cancer Facts and Figures 2016. Atlanta, Ga: Am. Cancer Society. 2016

3. Andrej U., Andreas K., Stefan E., Katharina Landfester; Paul W. et al. Omeprazole Inhibits Proliferation and Modulates Autophagy in Pancreatic Cancer Cells, LoS ONE | 2014; 6 :5.

4. Angelo De Milito, Elisabetta I., Mariantonia L., Francesco L., Massimo ., et al. Proton Pump Inhibitors Induce Apoptosis of Human B-Cell Tumors through a Caspase-Independent Mechanism Involving Reactive Oxygen Species, Cancer Res. 2007;67:5408-5417 .

5. Angelo De Milito, Rossella C, Maria L, Martina B, Manuela I. et al. pH-dependent antitumor activity of proton pump inhibitors against human melanoma is mediated by inhibition of tumor acidity, Inter. J. of Ca. 2010; 127: 207-219 .

6. Axelrod D, Burns K, Davis D, von Larebeke N."'Hormesis'-An Inappropriate Extrapolation from the Specific to the Universal".Inter. J. of Occu. and Enviro. Health 10 2004; 3: 335-9.
7. Blakley L, Sorrentino L .In Vitro Mutations in Dihydrofolate Reductase That Confer Resistance to Methotrexate: Potential for Clinical Application , Human mutation 1998; 11:259-263 .

8. Boya P, Kroemer G. Lysosomal membrane permeabilization in cell death. Oncogene 2008; 27 : 6434-6451.

9. Calabrese EJ, Baldwin LA. Hormesis: the doseresponse revolution Annu.Rev.pharmacol.Toxico. 2003;143:175-197.

10. Freshney RI. Culture of Animal Cells.( 3rd. Ed.).Wiley-Liss,U.s.A. 1994:7: 267-308.

11. Gao S, Yu B, Li Y, Dong W, Luo H.Antiproliferative effect of Octreotide on gastric cells mediated by Inhibition of $\mathrm{Akt} / \mathrm{PKB}$ and telomerase. World $\mathrm{J}$. Gastroenterol, 2003; 9: 2362-5.

12. Grewal J, Dellinger CA,Yung WK.Fatal reactivation of hepatitis $\mathrm{B}$ with temozolomide. $\mathrm{N}$ Engl J Med. 2007; 356:1591-1592.

13. Groth-Pedersen L, Jaattela M.Combating apoptosis and multidrug resistant cancers by targeting lysosomes. Cancer Lett. 2010: 05.021.

14. Gullatte MM, Gaddis J. Chemotherapy. In: Varrichio CG, ed. A Cancer Source Book for Nurses. 8th ed. Sudbury, Mass: Jones and Bartlett; 2004:103-130.

15. Johansson AC, Appelqvist H, Nilsson C, Kagedal $\mathrm{K}$, Roberg K, and Ollinger K. Regulation of apoptosis-associated - lysosomal membrane permeabilization. Apoptosis 15: 527-540.

16. Kaiser J. "Sipping from a Poisoned Chalice". Science 302 (5644) 2003: 376-9.

17. Mahoney DE, Gilliat E, Dawson S, Stockdale E, Lee SH. Vero Cell Assay for Rapid Detection of Clostridium perfringens Entertoxine.Applied and Environmental Microbiology. 1989: 2141-2143.

18. SAS. (2012): Statistical Analysis System. Version 9.1th ed. SAS. Inst. Inc. Cary. N.C. USA.(19)

19. Thun MJ, Jacobs EJ, Patrono C.The role of aspirin in cancer prevention. Nat. Rev. Clin.Oncol. 2012; 9: 259-267.

20. Ueda, K; Clark, DP; Chen, CJ; Roninson, IB; Gottesman, MM and Pastan, I. (1987): "The human multidrug resistance (mdr1) gene. cDNA cloning and transcription initiation". The Journal of Biological Chemistry 262 (2): 505-8. PMID 3027054 . 
21. Jumaa AH, Hussein SM. Study the in vitro effect of alcoholic extract of Prunus aremasia kernels, Methotreaxte, amygdalin and the combination between them on HeLa cell line. Iraqi J. of Ca. and Med. Gen., 2015; 8(2):101-108.

22. Jumaa AH. The cytotoxic effect of VincristineAmygdalin combination on (Hela cancer cell line). Iraqi J. of Ca. and Med. Gen., 2018; 9:2.

23. Jumaa AH, Al Uboody WSH, Hady AM.
Esomeprazole and Amygdalin combination cytotoxic effect on human cervical cancer cell line . J. of Pharma.1 Sci. Res., 2018;10(9):2236-2241.

24. Ung LY, Giou-Teng Y, Pei-Lun C, Hsu-Hung T, Tsai-Kun W, Yu-Ting H, Pei-Shiuna L, .et al. Dual role of acetaminophen in promoting Hepatoma cell apoptosis and kidney fibroblast proliferation, Mol. Med. Rep. 2014; 9: 2077-2084. 